\title{
EFFECT OF THE WIRE MESH REINFORCEMENT ON SOME PROPERTIES OF THE PRECAST CONCRETE TILES
}

\author{
Lecturer/Dr. Zainab M. R. ABDUL RASOOL, \\ University of Kerbala, College of Engineering, Department of Civil Engineering. \\ Email:zainabn8@yahoo.co.uk \\ Lecturer/ Laith MOHAMMED RIDHA MAHMMOD, \\ University of Kerbala, College of Engineering, Department of Civil Engineering. \\ Email:Iaithmrmahmood@gmail.com \\ Asst.Lecturer/ Mushtaq SADIQ RADHI, \\ University of Kerbala, College of Engineering, Department of Civil Engineering. \\ Email:mushtaq.sadiq@uokerbala.edu.iq
}

\begin{abstract}
The possibility of improving some properties of precast concrete tiles under static load has been studied in this research. The experimental approach was adopted in this research to investigate the effect of two types of wire mesh reinforcements on some properties of precast concrete tiles especially flexural failure load. The experimental program is divided into three groups with two ages of the test, the result of each age is an average of three specimens; the first group consists of six specimens which refer to reference tiles, the second group consists of eighteen specimens reinforced with different shapes of a metal wire mesh. The third group consists of eighteen specimens reinforced with different shapes of the plastic wire mesh. Three tests were conducted in this research, flexural failure load, density, and absorption. The main conclusion from this research is; the increasing in flexural failure load of specimens tiles according to reference tiles was $10 \%, 17 \%$ and $25 \%$ for tiles reinforced with square plastic wire mesh, stripe plastic wire mesh and specific plastic wire mesh, and 33\%, 35\% and $21 \%$ for square metal wire mesh, stripe metal wire mesh, and specific metal wire mesh respectively.
\end{abstract}

Keywords: Tiles, Metal, Wire mesh, Plastic, Flexural failure load, Reinforcements. 


\section{AL-QADISIYAH JOURNAL FOR ENGINEERING SCIENCES}

Vol. 11 , No. 2

ISSN: $1998-4456$

\section{INTRODUCTION}

Pre-cast concrete tiles are the construction material which is used in roofing or flooring and consists of cement, sand, and gravel with a maximum size of (12) $\mathrm{mm}$. Some material may be added such as the pigment in the colored surface of the upper tiles or other additives in such cases to improve the properties of the concrete used in its manufacture (Iraqi Specification No.1107, 1987)

(Shah and Key, 1972; Netlon, 1988; Engel and Bakis, 2001), through their researches, have reached that, there is a possibility to improve the properties of precast concrete tiles, especially resistance to flexural and impact through the using of reinforcements with different materials, such as fibers, since these materials will contribute to the followings:

1- Improving durability and sustainability.

2- Improving mechanical properties.

3- Increasing susceptibility of tiles to absorb shocks.

4- Decreasing damage ratio during transfers or sudden bumps.

5-Decreasing amount cracks poetic expected to occur during the molding and processing.

(Al-Mashhadani et al, 2007), studied the reasons for the repetitive failure during concrete tiles testing. In their experimental program, in addition to full-scale concrete tiles, cubes, prisms, and cylinders were prepared, the tiles were divided into two groups; the first one was cast with the same concrete mixture used in a local factory of tiles in Iraq, while the other group contained tiles with a new different mix design, to study the effect of mix proportion on the properties of tiles. The test results showed that the properties of the second group are better than that of the first one. This failure may be due to badly proportioned concrete or due to bad quality control such as curing conditions. A newly suggested model was cast and tested, by using the metal wire mesh addition to the same concrete proportion of group two, the test results showed the newly suggested tiles were more resistant to breaking by $(+21 \%)$ in comparison with the tiles without metal wire mesh.

Another study was conducted by (Thweny, 2013) to improve the properties of concrete roof tiles by using propylene-ethylene copolymer waste materials as a grid to reinforce the roof tiles, it was found that the flexural failure load for reinforced tiles increased by (81\%) when compared to that without reinforcement. Likewise, the impact resistance of the tiles was increased, which the required number of blows that cause failure 26 and 3 blows for the reinforcement tiles and without reinforcement tiles, respectively.

(Sahu and Jain, 2015) explored the compressive strength, splitting tensile strength and flexural strength properties of concrete reinforced with short discrete fibers. The study was carried out on concrete with (20) MPa compressive strength, the size of glass fibers used was (30) $\mathrm{mm}$ and the fiber content was varied from $(0 \%)$ to $(0.3 \%)$ of the total weight of concrete. In studying the above three properties no admixture was used. Some conclusions from this research, the strength of tiles increases and this increasing has been found with the addition of fibers, and the water absorption of the concrete also decreases with increase in fiber content.

Studying the output of (Darsana et al. 2016) reveals that natural fibers such as coir can be used for the improvement of concrete roof tiles. Through testing, it was identified that concrete roof tiles with coir fibers demonstrate better ductility relating to those of concrete flag without fibers. Moreover, the flexural failure load was increased by $25 \%$. 


\section{AL-QADISIYAH JOURNAL FOR ENGINEERING SCIENCES}

Vol. 11, No. 2

ISSN: $1998-4456$

\section{OBJECTIVE OF RESEARCH}

In spite of the frequent failure of precast concrete tiles in Iraq, especially with flexural failure load test and do not confirm the limits of Iraqi specification, this research aims to improve the properties of Iraqi precast concrete tiles and increase its flexural failure load. Thus, the objective of this study is to investigate the effect of wire mesh reinforcement on some properties of precast concrete tiles by utilizing two types of locally available wire mesh, plastic and metal, in different plan shape, grid orientation of each type on the main property (flexural failure load) that specify the concrete tiles that used in the roofing and flooring. Additionally the density and water absorption of specimens was also inspected.

\section{THE EXPERIMENTAL WORK}

The experimental part of this study involves casting (42) specimens of concrete tiles separated into three groups; each group was tested in two ages. Group one consists of six specimens; all specimens of this group were plain concrete without any reinforcement, these specimens considered as the control specimens as the same tiles available in local markets and already used in construction projects for roofing purposes. The second group consists of (18) specimen's reinforced with the metal wire mesh in three patterns, the first is a square shape, the second is a specific shape, and the third is reinforced by longitudinal strips. The third group consists of (18) specimen's reinforced by the plastic wire mesh in three patterns similar to the reinforcement of metal wire mesh.

\subsection{MATERIALS}

\subsubsection{CEMENT}

Sulfate resisting Portland cement manufactured in Iraq with the trademark of (Al-Jeser) was used throughout this investigation, its properties are listed in Table (1) and confirm the limits of (Iraqi Specification No.5, 1984).

Table 1. Physical and Chemical Properties of Cement

\begin{tabular}{|c|c|c|}
\hline \multicolumn{3}{|c|}{ Chemical Composition, \% } \\
\hline Oxide composition & \% Percent & $\begin{array}{c}\text { Limits of Iraqi Specification } \\
\text { No.5 / 1984 }\end{array}$ \\
\hline $\mathrm{SiO}_{2}$ & 21.10 & Not available \\
\hline $\mathrm{Fe}_{2} \mathrm{O}_{3}$ & 6.70 & Not available \\
\hline $\mathrm{Al}_{2} \mathrm{O}_{3}$ & 5.30 & Not available \\
\hline $\mathrm{CaO}$ & 58.20 & Not available \\
\hline $\mathrm{MgO}_{\mathrm{SO}}$ & 4.60 & $5.0 \%$ (Max) \\
\hline Loss on Ignition (L.O.I) & 2.10 & $2.5 \%$ (Max) \\
\hline Insoluble Residue (I.R) & 2.89 & $4.0 \%$ (Max) \\
\hline Lime Saturation Factor (L.S.F) & 0.74 & $1.5 \%$ (Max) \\
\hline \multicolumn{2}{|c}{0.81} & $0.66 \%-1.02 \%$ \\
\hline
\end{tabular}


AL-QADISIYAH JOURNAL FOR ENGINEERING SCIENCES
Vol. 11 , No. 2

ISSN: $1998-4456$

\begin{tabular}{|c|c|c|c|}
\hline \multicolumn{2}{|c|}{$\mathrm{C}_{3} \mathrm{~S}$} & 25.40 & Not available \\
\hline \multicolumn{2}{|c|}{$\mathrm{C}_{2} \mathrm{~S}$} & 41.33 & Not available \\
\hline \multicolumn{2}{|c|}{$\mathrm{C}_{3} \mathrm{~A}$} & 2.71 & 3.5 (Max) \\
\hline \multicolumn{2}{|c|}{$\mathrm{C}_{4} \mathrm{AF}$} & 20.39 & Not available \\
\hline \multicolumn{4}{|c|}{ Physical Properties } \\
\hline \multicolumn{2}{|c|}{ Properties } & Test Result & $\begin{array}{c}\text { Limits of Iraqi Specification } \\
\text { No.5/1984 }\end{array}$ \\
\hline \multirow[t]{2}{*}{$\begin{array}{l}\text { Time of Setting } \\
\text { (Vicat test) }\end{array}$} & $\begin{array}{l}\text { Initial Setting } \\
\text { (Min) }\end{array}$ & 85 & 45 (Min) \\
\hline & $\begin{array}{c}\text { Final Setting } \\
\text { (Min) }\end{array}$ & 410 & Not available \\
\hline \multirow{2}{*}{$\begin{array}{l}\text { Compressive } \\
\text { strength (MPa) }\end{array}$} & 3 Days & 18.1 & 15 (Min) \\
\hline & 7 Days & 26.3 & 23 (Min) \\
\hline
\end{tabular}

\subsubsection{FINE AGGREGATE}

Natural sand supplied from the Al - Ekhaider region was used in this investigation. The results of the tests showed that the grading and other properties confirm the limits (Iraqi Specification No.45, 1984), all properties are illustrated in Tables (2).

Table 2. Properties of Fine Aggregate

\begin{tabular}{|c|c|c|}
\hline $\begin{array}{c}\text { Sieve size } \\
(\mathrm{mm})\end{array}$ & $\begin{array}{c}\text { Cumulative } \\
\text { Passing\% }\end{array}$ & $\begin{array}{c}\text { Limits of Iraqi Specification } \\
\text { No.45/1984 }\end{array}$ \\
\hline 10 & 100 & 100 \\
\hline 4.75 & 90 & $90-100$ \\
\hline 2.36 & 76 & $75-100$ \\
\hline 1.18 & 67 & $55-90$ \\
\hline 0.600 & 50 & $35-59$ \\
\hline 0.300 & 17 & $8-30$ \\
\hline 0.150 & 3 & $0-10$ \\
\hline Material Finer than 75- $\mu \mathrm{m}$ & 3.20 & $5 \%$ (Maximum) \\
\hline (Sieve No. 200) & 0.296 & 0.5 (Maximum) \\
\hline SO3 & & \\
\hline
\end{tabular}




\section{AL-QADISIYAH JOURNAL FOR ENGINEERING SCIENCES}

Vol. 11 , No. 2

ISSN: $1998-4456$

\subsubsection{COARSE AGGREGATE}

Crushed gravel from (Al-Nba'ay) region with a maximum size of (10) $\mathrm{mm}$ was used throughout this investigation. All properties of the coarse aggregate are shown in Table (3). The obtained results indicate that the properties of coarse aggregate are within the requirements of (Iraqi Specification No.45, 1984).

\subsubsection{SPECIFICATIONS OF THE METAL AND PLASTIC REINFORCEMENT}

The metal and the plastic wire mesh, available in the local markets used in fencing of plants in gardens, were used in this study. These wire mesh used as reinforcement in concrete tiles, which placed in the tension zone of the tiles to have resistance to flexural strength. These wire mesh have square openings with dimensions of $(10 \times 10) \mathrm{mm}$. Three patterns of each type of wire mesh were used in this study in order to study the effect of the shape of reinforcement on flexural behavior of concrete tiles, the types of wire mesh and its patterns are shown in Figure (1).

Table 3. Properties of Coarse Aggregate

\begin{tabular}{|c|c|c|}
\hline $\begin{array}{c}\text { Sieve size } \\
(\mathrm{mm})\end{array}$ & Cumulative Passing\% & $\begin{array}{c}\text { Limits of Iraqi Specification } \\
\text { No.45/1984 }\end{array}$ \\
\hline 37.5 & 100 & 100 \\
\hline 20 & 100 & $95-100$ \\
\hline 10 & 54 & $30-60$ \\
\hline 5 & 3 & $0-10$ \\
\hline Material Finer than 75- $\mu \mathrm{m}$ & 1.40 & $3 \%$ (Maximum) \\
\hline (Sieve No. 200) & 0.087 & 0.1 (Maximum) \\
\hline
\end{tabular}

(A): metal wire mesh




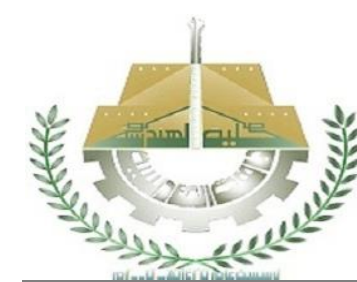

\section{AL-QADISIYAH JOURNAL FOR ENGINEERING SCIENCES}

Vol. 11 , No. 2

ISSN: $1998-4456$
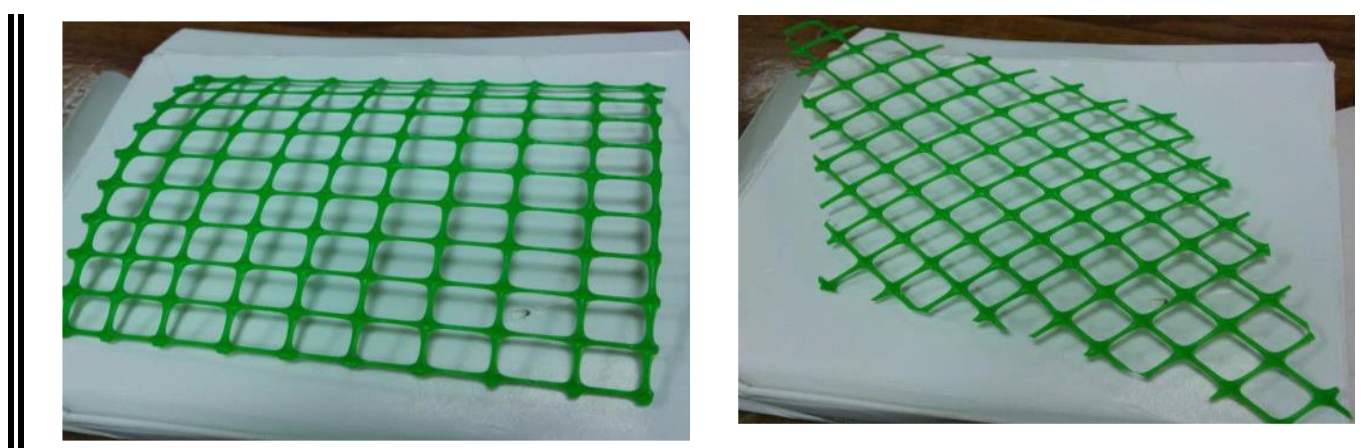

(B): plastic wire mesh

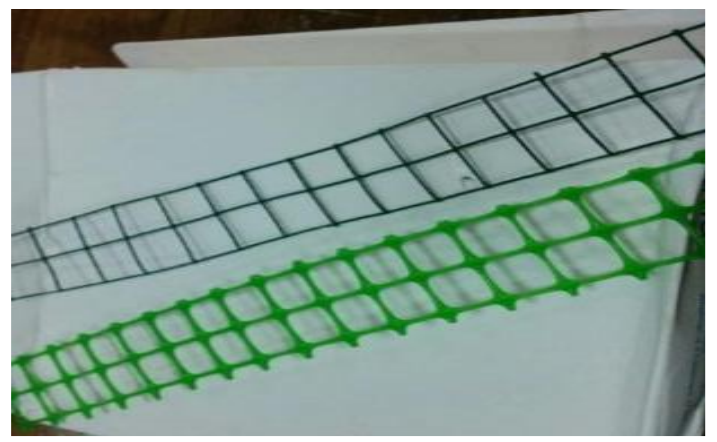

(C): longitudinal stripes of metal wire mesh and plastic wire mesh

Figure 1. Types and patterns of wire mesh used in this study

\section{DESCRIPTION OF THE TESTED SPECIMENS}

Three types of specimens were prepared in this study, the major one is precast concrete tiles with dimensions of $\left(400^{*} 200^{*} 50\right) \mathrm{mm}$ which conform the dimension of type (C) tiles as mentioned in Iraq Specification No.1107, 1987, in order to investigate the properties of tiles listed in Iraq Specification No. 1107, 1987 and they are flexural failure load, density; cubes specimens with dimension of $\left(100^{*} 100\right) \mathrm{mm}$ also prepared to determine compressive strength of concrete, and cylinder specimens with dimensions of $\left(100^{\star 2} 200\right) \mathrm{mm}$ to determine splitting tensile strength of concrete. The tiles specimens were divided into three groups, the details and the number of specimens in each group is shown below:

The first group consists of six tiles with the designation of (T1), three of them were tested at age of (14) days and the other three were tested at age of 28 days.

The second group consists of eighteen tiles reinforced with three patterns of the metal wire mesh with the designation of (T21), (T22) and (T23), where these sub-groups consists of six specimens. The first three of each sub-groups were tested at age of (14) days and the other three tested at the age of (28) days.

The third group also consists of eighteen tiles reinforced with three patterns of the plastic wire mesh with the designation of (T31), (T32) and (T33), where these sub-groups consists of six specimens. The first three of each sub-groups were tested at age of (14) days and the other three tested at the age of (28) days.

The dimensions and details of the tiles specimens in the three groups are shown in Figure (2). 


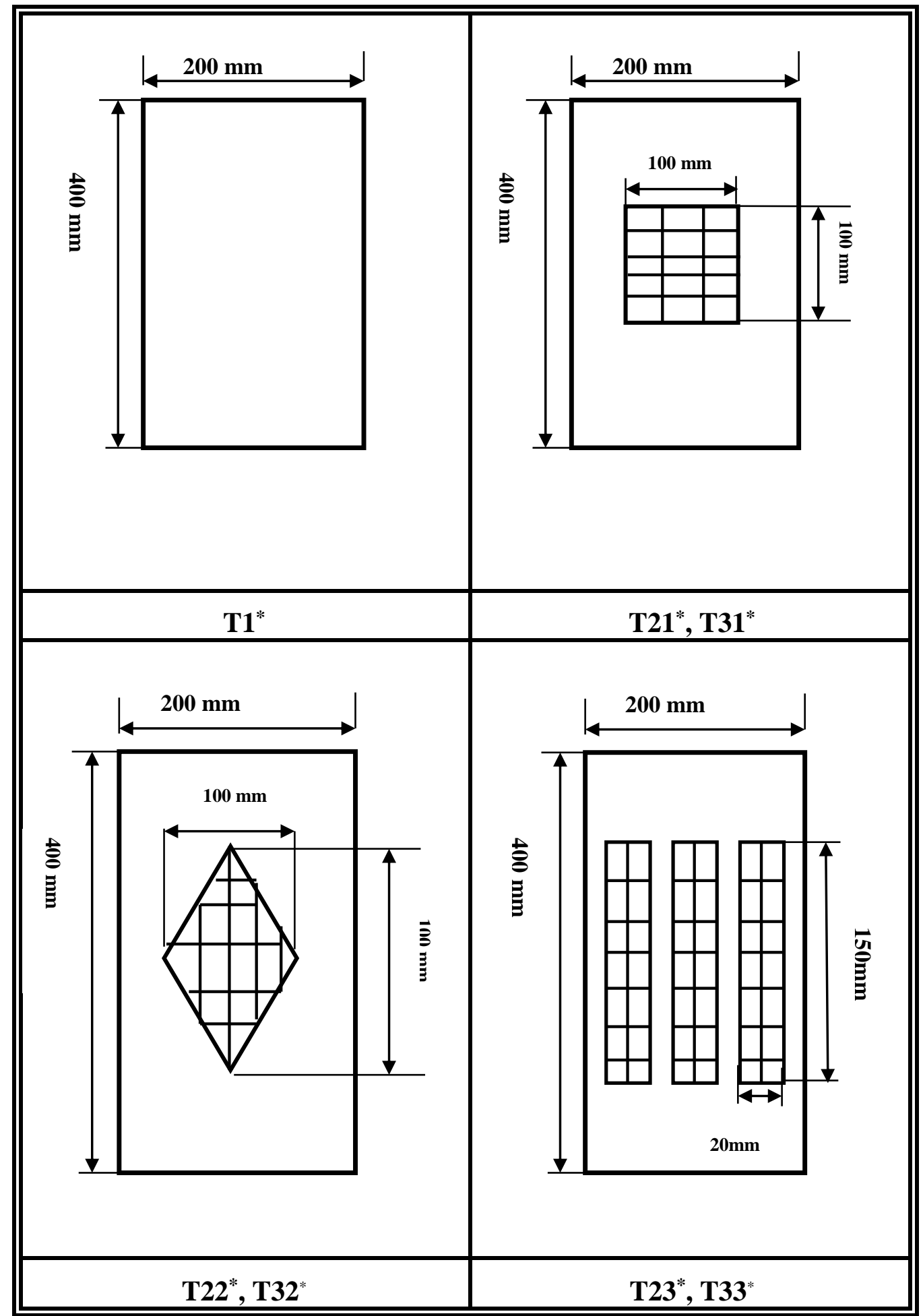

* This mark refers that the number of casted tiles is six.

Figure 2. The Details of Tiles 


\section{AL-QADISIYAH JOURNAL FOR ENGINEERING SCIENCES}

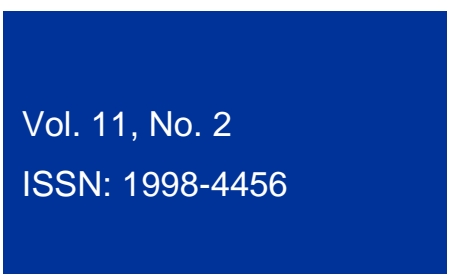

\subsection{DESIGN AND MIXING OF CONCRETE}

British Building Research Establishment method (Teychenne, 1997) was adopted in this research to design the ordinary concrete, which is used in preparing all tiles specimens with and without reinforcement. The details of mix proportion are listed in Table (4). The preliminary tests show that the compressive strength is (18.7 MPa and 22.3 MPa) in age (7), (28) days, respectively, this test was conducted according to British Standard (B.S.1881:116, 1983). Whereas the test results show that the splitting tensile strength is $(1.75$ $\mathrm{Mpa}, 2.1 \mathrm{MPa}$ ) in age (7), (28) days, respectively, this test was performed based on test method reported in (ASTM C 496,2011 ).

Table 4. Mixture Proportion

\begin{tabular}{|c|c|c|c|}
\hline Cement $(\mathrm{Kg} / \mathrm{m} 3)$ & $\begin{array}{c}\text { Coarse Aggregate } \\
(\mathrm{Kg} / \mathrm{m} 3)\end{array}$ & $\begin{array}{c}\text { Fine Aggregate } \\
(\mathrm{Kg} / \mathrm{m} 3)\end{array}$ & Water $(\mathrm{Kg} / \mathrm{m3})$ \\
\hline 390 & 1040 & 760 & 195 \\
\hline
\end{tabular}

Concrete is mixed in a small laboratory drum-type mixer with a capacity of $(0.05) \mathrm{m} 3$, the mixing procedure was performed according to (ASTM C192, 2015). Any residual particles of concrete from a prior batch were cleaned before using the mixer, then it was cleaned with a moist cloth to clean the blades and drum of the mixer.

Firstly the coarse aggregate with some of mixing water was added into the mixer before starting it, the mixer turns on and the fine aggregate, cement, water were added to the mixer rotate, the all ingredients mixing together for (3) minutes in the drum of mixer followed by (3) minutes rest, during this period the top of the mixer was covered with polyethylene sheet to prevent evaporation, then mix again for (2) minutes as a final mixing, the mixture was discharged from the mixer and the casting of specimens start.

\subsection{CASTING AND CURING PROCEDURE}

The moulds used for casting tiles specimens were MDF wood with specifying dimensions confirming (Iraqi Specification No.1107, 1987). Each mould consists of a bed and four movable sides, the sides were fixed to the bed with screws. The clear dimensions of the moulds were $(400 \times 200 \times 50) \mathrm{mm}$. Figure (3) shows the moulds used in the study to prepare tiles.

Before casting, all moulds were well cleaned and their internal surfaces were lightly oiled to avoid the adhesion of hardening concrete to them. All moulds were filled with concrete except the tiles reinforced by wire mesh were casted in two layers and placed the wire mesh in the one third lower of tiles. The tiles, cubes, and cylinders were vibrated by placing them on the vibration table and were covered with polyethylene sheets to prevent evaporation of water. After (24) hours from casting, the specimens were demolded and cured by placing them in the curing tanks which filled with tap water until the time of testing.

\subsection{SPECIMEN PREPARATION AND TESTING}

After casting and curing of specimens until the day of testing, all cubes were tested with compressive strength machine according to British Standards (B.S. 1881:116, 1983), and all cylinders were tested with compressive strength machine to determine the splitting tensile strength according to (ASTM C-496,2011). The flexural failure load test of the tiles specimens was conducted according to the (Iraqi Specification No.1107, 1987). 


\section{AL-QADISIYAH JOURNAL FOR ENGINEERING SCIENCES}

Vol. 11, No. 2

ISSN: $1998-4456$

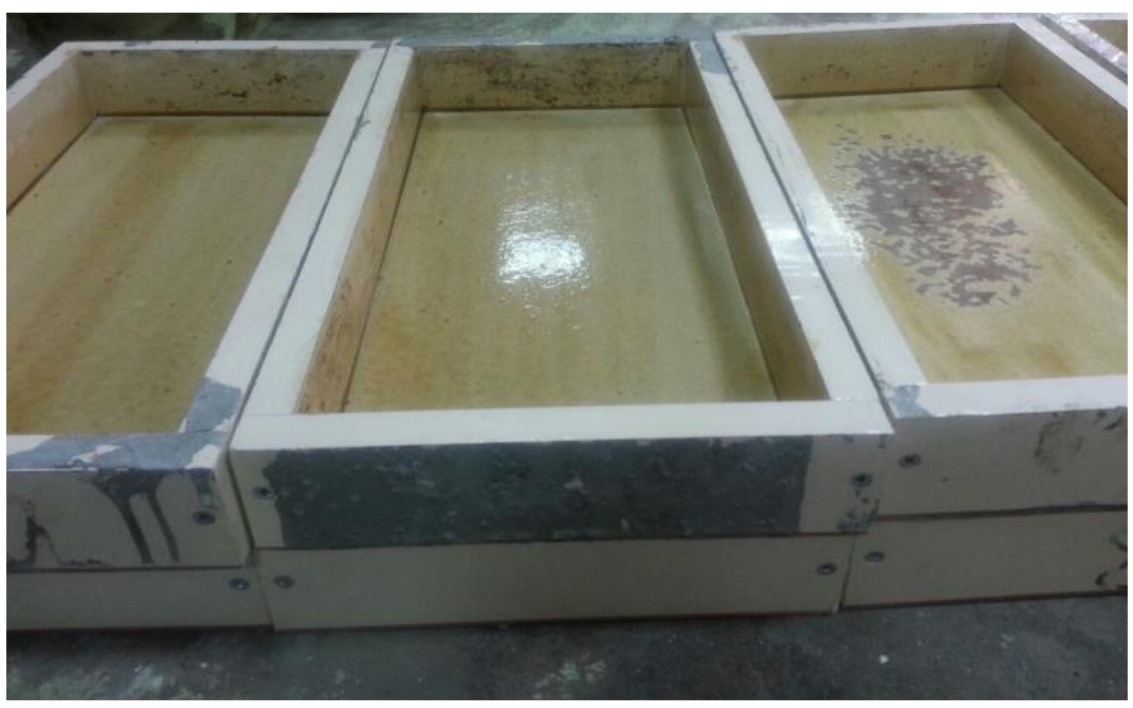

Figure 3. The moulds used in this study

\section{RESULTS AND DISCUSSION}

\subsection{FLEXURAL FAILURE LOAD}

This test is one of the most important tests, which has been carried in the tiles, the specimen was fixed in the test machine to obtain a simply supported condition at distance $(5) \mathrm{cm}$ from each end and subjected to concentrated load applying on the center of the specimen provided by wood plate with width (10) $\mathrm{mm}$, as shown in Figure (4), the load is applied homogeneity and continuously until the failure.

The lower limit of flexural failure load was $(4.4 \mathrm{kN})$, according to the Iraqi Specification of the flag type (C) with dimensions $\left(200^{*} 400^{*} 50\right) \mathrm{mm}$.

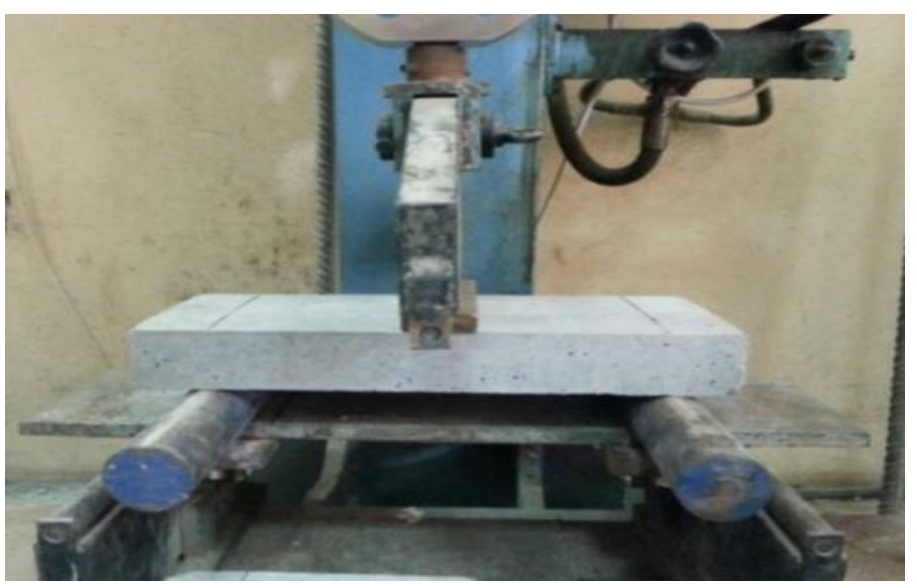

Figure 4. Test of Tiles Specimen 


\section{AL-QADISIYAH JOURNAL FOR ENGINEERING SCIENCES}

Vol. 11, No. 2

ISSN: $1998-4456$

From Table (5) and Figure (5), it can be distinguished that the flexural failure load for all specimens confirmed the limit of (Iraqi Specification No.1107, 1987). The test results shown improving flexural failure load for all reinforced tiles comparing with control specimen without reinforcements. The percentages of increasing of flexural failure load relative to the control specimen in the age of (14) days are (5) \%, (14) \%, and (23) \% for square, strips, and the specific shape of plastic wire mesh reinforcement, respectively. Whereas the percentages of increasing are (18) \%, (18) \%, and (20) \% for square metal, strips, and the specific shape of plastic wire mesh reinforcement, respectively.

While the percentages of increasing at age of (28) days are (10) \%, (17) \%, and (25) \% for square, strips, and the specific shape of plastic wire mesh reinforcement, respectively. Whereas for tiles reinforced with a metal wire mesh with square, strips, and specific patterns flexural failure load is increased by a percentage of $(33) \%$, (35) \%, and (21) \%, respectively. The cause of increasing in flexural failure load denoted to reinforcement which used to strengthen the tension zone of tiles by metal and plastic wire mesh so that this wire mesh worked to increase the strength of tiles to flexure.

Table 5. Results of Flexural Failure Load of Concrete Tiles

\begin{tabular}{|c|c|c|c|}
\hline \multirow{2}{*}{ Tile Type } & \multicolumn{3}{|c|}{ Flexural failure load (kN) } \\
\cline { 2 - 3 } & At age 14 days & At age 28 days & $\begin{array}{c}\text { Limits of Iraqi } \\
\text { Specification No.1107 / } \\
1987\end{array}$ \\
\hline Control (T1) & 4.4 & 4.8 & \\
\hline Square plastic (T21) & 4.6 & 5.3 \\
\hline Specific plastic (T22) & 5.4 & 6.0 & \multirow{2}{*}{4.4} \\
\hline Strips plastic (T23) & 5.0 & 5.6 \\
\hline Square metal (T31) & 5.2 & 6.3 \\
\hline Specific metal (T32) & 5.3 & 5.8 \\
\hline Strips metal (T33) & 5.2 & 6.5 \\
\hline
\end{tabular}

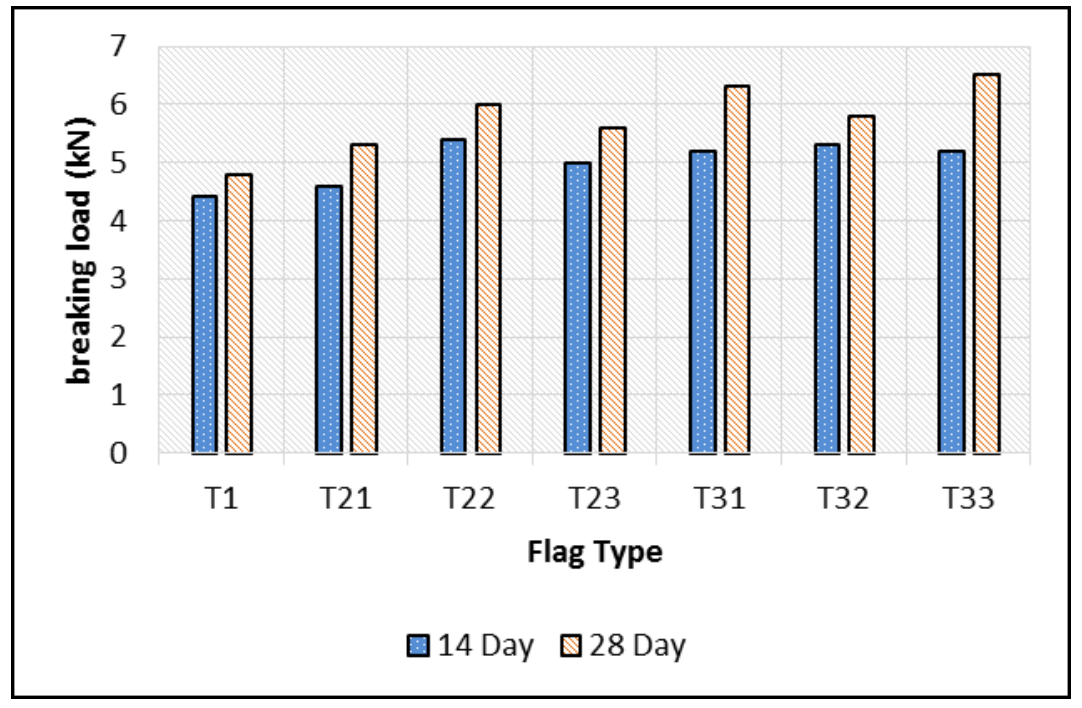

Figure 5. Flexural Failure Load at Different Ages 


\section{AL-QADISIYAH JOURNAL FOR ENGINEERING SCIENCES}

Vol. 11 , No. 2

ISSN: $1998-4456$

\subsection{DENSITY}

The dimensions (length, width, and height) were measured in this test for each tile, and the average of the measurements from three different positions for each dimension was taken, forward the mass of each tile was measured by electric balance, and calculated the density by dividing the mass on the volume of each specimen (Neville and Brooks 2010),( Neville, 2011).

It can be noted that from Table (6) and Figure (6) an increment of the density of reinforced tiles comparison with control specimen, and little difference between density values of reinforced tiles. The increment ratios of density are $(0.85) \%,(0.89) \%,(0.76) \%,(0.93) \%,(0.89) \%$, and $(1.1) \%$ for tile reinforced with square plastic, specific plastic, strips plastic, square metal, specific metal, and strip metal, respectively. There is a little effect on the density of tiles by reinforcing them with metal and plastic wire mesh and can be considered negligible, this behavior may be due to the small thickness of reinforcing materials relative to that of tiles, and little weight of clams comparing with concrete ingredients.

Table 6. Results of Density of Concrete Tiles

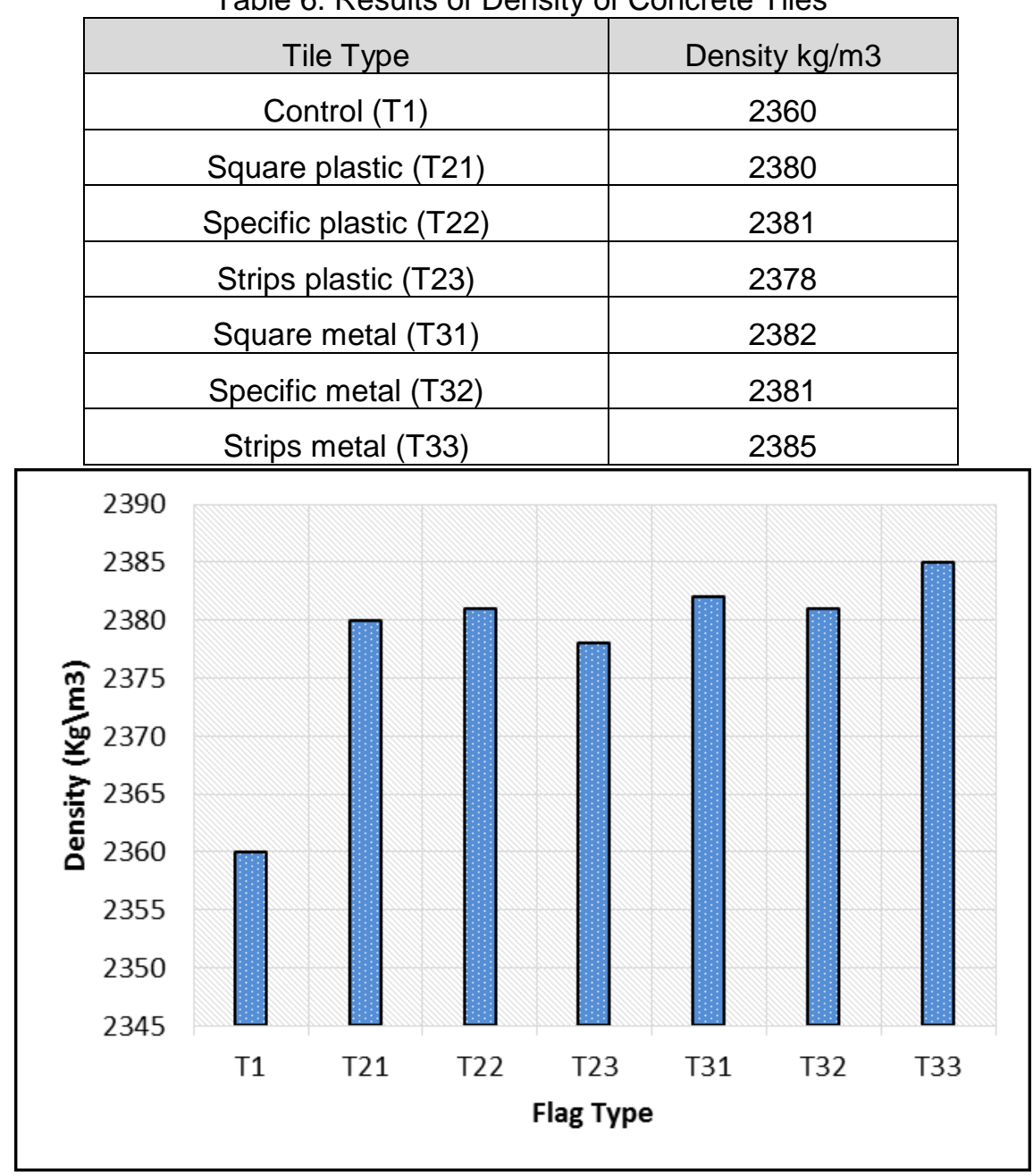

Figure 6. Density at Different Ages 


\section{AL-QADISIYAH JOURNAL FOR ENGINEERING SCIENCES}

Vol. 11 , No. 2

ISSN: $1998-4456$

\subsection{ABSORPTION}

An electric furnace was used for drying the tiles specimens for (24) hours, after that they were removed to cool in air and then the dry weight was recorded. The tiles were placed in a water tank, after (24) hours the samples were removed and the outer surface was dried with a piece of fabric to get the saturated surface dry condition, this weight also recorded for each sample to calculate the absorption ratio. The results of the water absorption of concrete tiles are demonstrated in Table (7) and schemed in Figure (7), it is directed that the water absorption for all reinforcement concrete tiles decreased as associated with the concrete tiles without reinforcement. Furthermore, all water absorption results agree with (Iraqi Specification No.1107, 1987) limits (rate of absorption less than 10). The percentage of decrease for the plastic wire mesh (21) \%, (26) \%, and (19) \% to square, stripe, specific respectively as compared to control tiles. However, the percentage of decreased for the metal wire mesh (47) \%, (54) \%, and (51) \% for square, stripe, specific correspondingly as related to control tiles. That trend may attribute to the ability of both wire mesh reinforcement to control cracks distribution leading to diminishing the water absorption of concrete tiles.

Table 7. Results of Absorption of Concrete Tiles

\begin{tabular}{|c|c|c|}
\hline Tile Type & $\begin{array}{c}\text { Absorption\% } \\
\text { (24 hours) }\end{array}$ & $\begin{array}{c}\text { Limits of Iraqi } \\
\text { Specification No.1107 / } \\
1987\end{array}$ \\
\hline Control (T1) & 5,7 & \\
\hline Square plastic (T21) & 2.3 & \\
\hline Specific plastic (T22) & 3.0 & \multirow{2}{*}{10} \\
\hline Strips plastic (T23) & 3.9 & \\
\hline Square metal (T31) & 2.8 & \\
\hline Specific metal (T32) & 3.0 \\
\hline Strips metal (T33) & 2.6 \\
\hline
\end{tabular}

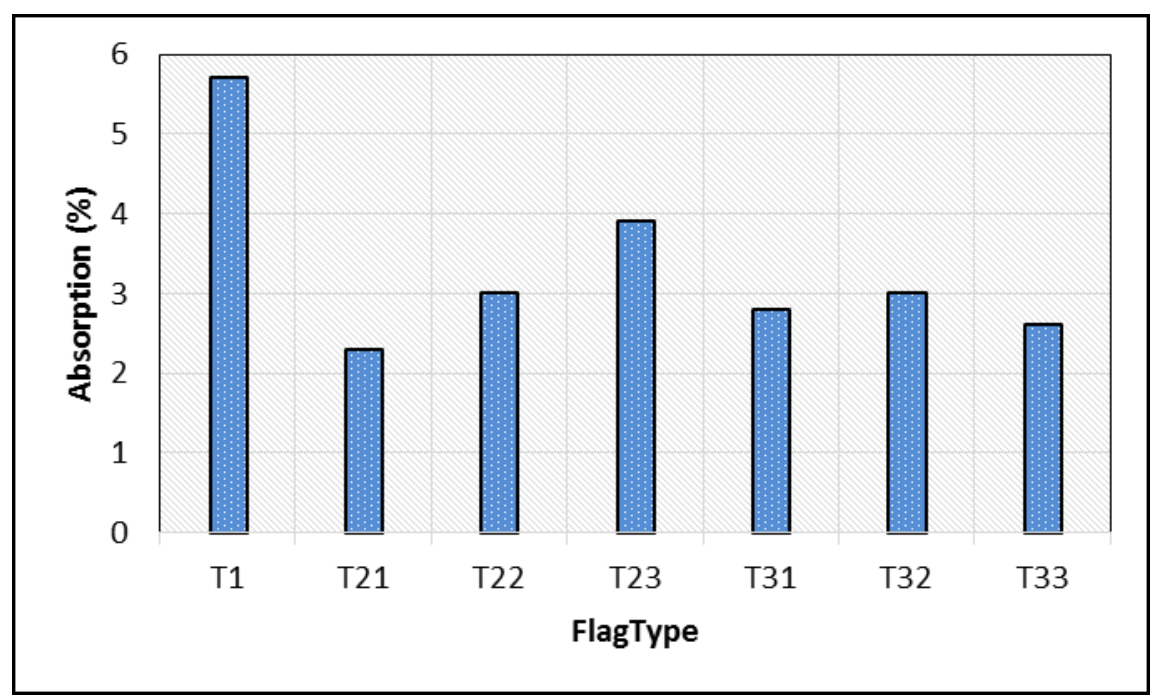

Figure 7. Water Absorption at Different Ages 


\section{CONCLUSIONS}

The objective of this investigation was to assess the effects of wire mesh reinforcement on some properties of the concrete roofing tiles, which are plastic and metal wire mesh. Conclusions depend on test results can be summarized as follows.

Metal wire mesh and plastic wire mesh can be effectively employed as reinforcement for the concrete tiles. Though, the metal wire mesh reinforcement is more beneficial over plastic wire mesh reinforcement in regards to water absorption and flexural failure load.

The better pattern of reinforcement in flexural failure load of the concrete tiles for the metal wire mesh is strips, square and then specific. Whereas, the better pattern for the plastic wire mesh is specific, the strips and the square.

In terms of durability, the water absorption test results set that both metal wire mesh and plastic wire mesh exhibited a worthy decline in the water absorption. That trend attributed to the ability of both wire mesh reinforcement to control cracks distribution leading to diminishing the water absorption of concrete tiles.

The trend of the shape of the reinforcement of water absorption of concrete tiles is similar to that in the flexural failure loads, the strip's shape the best in the metal wire mesh and the specific shape is the best in the plastic wire mesh.

The use of wire mesh reinforcement in the concrete tiles is not significant effect on the density of the tiles, the increase in the density of the tiles not more than $1 \%$.

\section{REFERENCES}

1. Al-Mashhadani, S.A., Al-Attar, T.S., Al-Khateeb, A.M. Developing of Concrete Tiles, Journal of Engineering, Vol.12, No.2, 2006.

2. ASTM C 496. Splitting Tensile Strength of Cylindrical Concrete Specimens, Annual Book of ASTM Standard 2015.

3. ASTM C 192. Making and Curing Concrete Test Specimens in the Laboratory, Annual Book of ASTM Standard 2015

4. British Standards Institution. B.S 1881, Part 116. Method for Determination of Compressive Strength of Concrete Cubes, 1983.

5. Darsana, P.R.A., Jasheela, A.J.A., Binuraj, P.R., Sarma, J. Development of Coir-Fiber Cement Composite Roofing Tile, Procedia Technology, 24, P. 169 - 178, 2016.

6. Engel, R.S. and Bekis, C.E. Fiber Reinforced Polymer-grids for Reinforced Concrete, National Science Foundation Center, June, 2001.

7. Iraqi Specification No.5. Portland Cement, Central organization for standardization and quality control, Ministry of planning, 1984. 
8. Iraqi Specification No.45. Aggregate from Natural Sources for Concrete and Construction, Central organization for standardization and quality control, Ministry of planning, 1984.

9. Iraqi Specification No.1107. Precast Concrete Flags, Central organization for standardization and quality control, Ministry of planning, 1987.

10. Netlon. Tensor Grids in Concrete Applications, The Civil Engineering Division, Blackburn, December, 1988.

11. Neville, A. M., and Brooks, J. J. Concrete Technology, Pearson, 2nd edition, 2010.

12. Neville, A.M. Properties of Concrete, Fifth Edition, Pearson, 2011.

13. Sahu, S.K. And Jain, J.K. Effect of Chopped Glass Fibers on The Strength of Concrete Tiles, thesis, B. Tech and M. Tech (Dual) in Civil Engineering Specialization Structural Engineerin, ROURKELA769008, 2015.

14. Shah, S.P. And Key, W.H. Impact Resistance of Ferro Cement, ASCE Proceedings, Journal of Structural Division, January, 1972

15. Thweny, Z.A. Using Propylene-Ethylene Grid to Improve the Production of Precast Concrete Slabs, Eng. \& Tech. Journal, Vol.31, No.4, 2013.

16. Teychenne, D.C., Franklin, R.E., Erntroy, H.C. Design of Normal Concrete Mixes, Watford, U.K., Building Research Establishment, 1997. 